\title{
THE ROLE OF HEADMASTER IN BUILDING ENTREPRENEURIAL SPIRIT IN STUDENTS
}

\author{
Nur Indah Lailya Mawar Sari ${ }^{1}$ Sukarno $^{2}$ Triyanto $^{3}$ \\ ${ }^{123}$ Universitas Sebelas Maret Surakarta, Indonesia \\ Nur Indah Lailya Mawar Sari lya.indah_ms@student.uns.ac.id
}

\begin{abstract}
The objective of this study is to determine the role of the headmaster in building the entrepreneurial spirit of students. This study used a qualitative descriptive approach with objects namely the headmaster. The data collection techniques conducted through interviews and observation. The results found that the headmaster has a very important role in building the entrepreneurial spirit of students by creating new innovations in developing entrepreneurship, providing motivation or encouragement to the students, and giving direction to the students to build entrepreneurial spirit. The headmaster builds the entrepreneurial spirit of students who will make a positive contribution so that students can learn to be self-employed and as a valuable provision for their future
\end{abstract}

Keywords

Headmaster, Students, Entrepreneur, Elementary School

Article Received: 18 October 2020, Revised: 3 November 2020, Accepted: 24 December 2020

\section{Introduction}

Technological advances are increasingly shifting and changing the patterns of human work which originally use human labor and now use a machine. This has positive and negative effects on humans. On one side, a human beingis facilitated with various technologies, tools, and machines that can facilitate human work, but on the other hand, human workers are replaced by machinery that causes a lot of unemployment. Referring to data from the Central Bureau of Statistics (BPS) in August 2018, the Open Unemployment Rate (TPT) is still at 5.34 percent, which means that there are still 7 million unemployed people. This can affect economic development in Indonesia. Successful entrepreneurship is a long process because a successful entrepreneur will have the provision and guidance in dealing with the business that they run and need for training and learning. Because the challenges of entrepreneurship are very complex so it needs strong people with skills to become successful entrepreneurs.The need for early learning and education in entrepreneurship for children stated by Winerungan (2017) in an interview with Republika. He said that the government need to issue policies related to education about the importance of entrepreneurship being taught starting from elementary school (SD), because if they had been trained since childhood, then their entrepreneurial spiritwill be stronger, so that when they graduate, they can open their own employment but in fact, many graduates are unemployed, and there is no alternative to entrepreneurship because they do not have the provision of learning about entrepreneurship. To create students who have high entrepreneurial spirit, it needs some efforts from the surrounding environment and the school environment. In the school environment, the teachers and the headmaster are required to have an active role in developing entrepreneurship in schools, especially as the headmaster who become the school leaders who determine whether or not the school is progressing.

Kebakkramat Elementary school is one of the elementary schools that develop entrepreneurship that involves students in their development. In its development, the role of teachers and headmaster is needed in building the entrepreneurial spirit of students. Entrepreneurial spirit need to be developed in students from an early age so the entrepreneurial spirit of students can be right on target and it needs mentoring and direction by teachers and headmaster. In particular for the headmaster who leads a school and determines the policies that are implemented in school. The role that the headmaster must have in implementing 
entrepreneurship for elementary school students among others are: 1) encouraging the growth of school community involvement. 2) Conducting guidance for school community 3) Building relationships with the community, there is a need for communication and relationships with the surrounding community through school committees which are usually formed by each school. 4) Building relationships/cooperation or related institutions and in accordance with entrepreneurship, agencies or institutions that exist around the school and collaborate to improve and achieve entrepreneurial goals (Sugiyar, 2014, p. 123). The headmaster as policymakers in schools should be able to serve maximally. The headmaster can lead schools wisely and lead to achieving maximum goals to improve the quality of education in schools which of course will affect the quality of graduate students so that they can make proud and save a bright future (Wiyatno, Muhyadi, 2013, p. 165).

If the headmaster does not play a maximum role in building entrepreneurial spirit of the students, it will make the business run less successful. Although every entrepreneur wants the best results. Based on these problems it is necessary to have the role of the headmaster in building student entrepreneurship so the students can be directed at entrepreneurship in order that the business developed can be successful.

\section{Methodology}

This study used a descriptive type of research with a qualitative approach. As stated by Sugiyono (2016: 1) qualitative research is a study with natural object conditions, researchers act as key instruments with data collection techniques using interview and observation. Researchers using a qualitative descriptive approach to determine the role of headmaster in building entrepreneurial spirit of the students. The subject of this study consisted of the headmaster and 2 teachers and 2 students at Kebakkramat Elementay school. The number of respondents was 5 (five). In this study, we try to look closely at the informants who know about the topic under discussion to get information.

\section{Results}

Based on the results of interviews with the headmaster and the teachers about the role of headmaster in building the entrepreneurial spirit of the students. In (National Education Regulation of Republic of Indonesia Number 13 of 2007 Standards for Headmaster/ principal from Islamic school) the competencies that must be achieved by the headmaster in developing entrepreneurship are 1) Creating innovations that are useful for the development of public schools/Islamic schools. 2) Work hard to achieve public schools/Islamic schools success as an effective learning organization. 3) Having a strong motivation to succeed in doing their main tasks and functions as a leader of public schools/Islamic schools. 4) Never give up and always look for the best solutions in dealing with obstacles faced by public schools/Islamic schools. 5)Having entrepreneurial instincts in managing production activities/school services/Islamic school as learning resources for students. This is supported by (Regulation of Minister of Education and Culture No. 6 of 2018 Article 15 about the Assignment of Teachers as Headmaster) to be one of the main tasks that must be developed by the headmaster, namely entrepreneurship. The headmaster in leading entrepreneurship should do the following: 1) encouraging the growth of students with the school community, 2) conducting guidance to the school community to improve and develop schools, 3) building good relations with the community and cooperate with institutions or agencies in accordance with the entrepreneurship that developed at school.

From the statement that has been explained before, it can be concluded that in developing entrepreneurship in elementary schools, headmaster must be able to: 1) Create innovations that are useful for school development, 2) Encourage the growth of students for entrepreneurship, 3) doing coaching to the school community to improve and develop schools 4) build good relations with the community and cooperate with institutions that are in accordance with the entrepreneurship developed in schools.In the implementation of entrepreneurship in elementary schools there needs to be roles and participation of the school community. 
Particularly, the role of the headmaster as a leader in the school environment. A leader is not only a person who leads an institution but also must be able to provide examples, direction and guidance for his subordinates and utilize all available resources in the school environment, this is stated by (Permadi, 2017, p. 24).

The role of the school principal in building entrepreneurialspirit in elementary schools is by:

1) Creating innovations that are useful for school development

This elementary school has a narrow and the efforts made by the headmaster, namely by using the narrow area and the number of students classified as many. "The headmaster contributed his idea by proposing entrepreneurship in this elementary school by simple cultivation or school garden by using bamboo shelves in the school environment" (teacher interview on March 2, 2019). The headmaster is required to innovate in developing entrepreneurship at SDN Nangsri Kebakkramat 01. This is supported by the statement that the ability of headmaster who has an entrepreneurial spirit in innovation greatly determines the success of the school they lead because the headmaster can respond to every need, desire, and expectation of the community for educational services for their children. If the headmaster wants to be successful in leading a school, be creative and innovative individuals in implementing or building the potential of their creativity in the form of valuable innovations by Sudrajad (2010).

The headmaster also develops entrepreneurship through handicrafts taught to the students. As stated by (Sumanto, 2018, p. 51) Handicrafts can be used as contextual and actual learning resources so it can be used by the teachers as teaching tools and for the students as learning resources in accordance with the competency of learning outcomes that they will achieve.

From the observations on March 1, 2019, that the handicrafts developed in this school have high aesthetic value from making ashtrays, pencil cases with origami paper, making flower vases and making patchwork brooches and the creation of brooches from the banana stem that have been dried. The honesty cooperative and rental canteen also include innovations that have been developed by the headmaster. Honesty is fundamental to be applied to the students

"I am happy if the headmaster encourages me to do it in order to be better" (student interview on March 5, 2019). The headmaster in creating this innovation contributes to students in order to work hard, creative innovation and innovative, independent, and honest."

2) Encouraging and motivating the growth of students for entrepreneurship.

Motivating children is essential because children often feel inferior to what they are doing (The headmaster interview on March 1, 2019). This is in line with what expressed by the teacher that "The headmaster in every entrepreneurial activity in schools often monitor and motivate the students by assisting each student in entrepreneurship "(Teacher interview on March 2, 2019). "Motivation is fundamental to be known by educators so that the results of learning achievement can be attained without catalyzed by other factors" (Triyanto, 2019). Motivation is very necessary for students because it is a fundamental thing that must be developed by every educator. As an educator, it is an obligation to help and encourage students to try again or improve their work. Giving motivation to students will foster an entrepreneurial spirit, hard work, creative, and innovative.

3) Coaching the school community to improve entrepreneurship.

Coaching is an effort carried out consciously, seriously, planned and consistently by guiding, directing and developing skills, knowledge, and practice (Manan, 2017, p. 52). "The principal conducts coaching particularly on Mondays during flag ceremonies and during teacher meetings which are held once a week" (teacher interview on March 2, 2019). In conduct coaching, the headmaster is directing and dividing the tasks in managing entrepreneurship in schools. "The headmaster often visit the class to ask about the student activities" (students interview on March 5, 2019). In addition to conduct coaching 
during meetings and after the flag ceremony. The headmaster also conducts coaching in each class. This coaching intends to provide students in entrepreneurship and listen to students' aspirations in entrepreneurship and as a means for question and answer in the advantages and disadvantages that happen in entrepreneurship.

Conclusion

Entrepreneurship needs to be developed early on especially in elementary school students as a provision and habituation for the students to innovate, be creative and have an entrepreneurial spirit. The headmaster as leaders and policymakers have a crucial role to play in the progress of the school. Based on the discussion, it can be concluded that the headmaster one of Kebakkramat Elementay school plays a role in the development of entrepreneurial spirit and skills of the students by creating innovation, giving motivation to students, and providing guidance to students.

\section{REFERENCES}

[1] Avianti, F. S. (2016). Implementasi Kewirausahaan Kepala Sekolah dalam Pengembangan Kewirausahaan di SMK 1 Kota Tangerang Selatan. Jurnal Kependidikan .

[2] Daryanto, A. D. (2013). Kewirausahaan (Penanaman jiwa Kewirausahaan). Yogyakarta: Gavamedia.

[3] Frinces, Z. H. (2011). Kepemimpinan Berbasis Kewirausahaan. Jogjakarta: Media Pustaka.

[4] Hole, Y., \& Snehal, P. \& Bhaskar, M. (2019). Porter's five forces model: gives you a competitive advantage. Journal of Advanced Research in Dynamical and Control System, 11 (4), 1436-1448.

[5] Kompri. (2014). Manajemen Sekolah Orientasi Kemandirian Kepala Sekolah. Yogyakarta: Pustaka Pelajar.

[6] Manan, S. (2017). Pembinaan Akhlak Mulia Mengenai Keteladanan dan Pembiasaan. Jurnal Pendidikan Agama Islam -Ta'lim , 5 (1).

[7] Permadi, D. (2017). Kepala Sekolah. Bandung: PT Sarana Panca Karya Nusa.

[8] Riani, A. L. (2014). Dasar-Dasar Kewirauasahaan. Surakarta: UNS Press.

[9] Robert D Hisrich, M. P. (2013). Entrepreurship Ninth Education. Singapore: McGraw-Hill Education.

[10] Said, A. (2018). Kepemimpinan Kepala Sekolah dalam Melestarikan Budaya Mutu Sekolah. Evaluasi , 2 (1), 257.

[11] Sugiyar. (2014). Peran Kepala Sekolah Dalam Implementasi Pendidikan Kewirausahaan. Jurnal Kebudayaan dan Kebudayaan, 9 (1).

[12] Sugiyono. (2016). Memahami Penelitian Kualitatif. Bandung: Alfabeta.

[13] Sumanto. (2018). Keagaman jenis model produk Home Industry. Sekolah Dasar: Kajian Teori dan Praktik Pendidikan, 51.

[14] Triyanto. (2019). The Academic Motivation of Papuan. SAGE Open , 5.

[15] Wiyatno, Muhyadi. (2013). Peran Kompetensi Kewirausahaan Kepala Sekolah Dalam Peningkatan Mutu Pendidikan di SMP N 3 Jetis, Batul. Akutabilitas Manajemen Pendidikan

164. 